\title{
Anaplastic Pancreatic Carcinoma Arising Within a Mucinous Cystic Neoplasm of the Pancreas: A Case Report and a Brief Review of the Literature
}

\author{
Alessandro Paniccia, ${ }^{1}$ Robert Torphy, ${ }_{1}^{1}$ Kalpana Devaraj, ${ }_{1}$ and Richard D. Schulick,
}

\begin{abstract}
Background: Anaplastic pancreatic carcinomas (APCs) are among the least frequently encountered pancreatic malignancies, ranging from $0.5 \%$ to $7 \%$ of all nonendocrine pancreatic malignancies. Furthermore, few cases of APCs have been described arising within a pancreatic mucinous cystic neoplasm (MCN).

Case Presentation: A 36-year-old female presented with left upper quadrant pain and a $10 \times 8 \mathrm{~cm}$ complex cystic mass in the pancreatic tail. Fine needle aspiration of the cyst showed papillary clusters of cells with mild cytological atypia, cyst fluid carcinoembryonic antigen $>4000 \mathrm{ng} / \mathrm{mL}$, and amylase of $25 \mathrm{U} / \mathrm{L}$. After an open distal pancreatectomy and splenectomy, the specimen revealed an MCN with multifocal microscopic foci of invasive welldifferentiated adenocarcinoma. After additional sampling, foci of undifferentiated malignancy-morphologically resembling sarcomas but with immunohistochemical staining consistent with anaplastic carcinoma-were identified. The patient had an uneventful recovery and is currently undergoing a regimen of gemcitabine-based adjuvant chemotherapy; she remains disease-free at 5 months after initial diagnosis.

Conclusions: In this study, we describe a rare case of APC originating from a large pancreatic MCN lesion. This case underlines the importance of scrupulous pathological evaluation of the entire MCN epithelium and adds to the limited world literature of APC originating from pancreatic MCN lesions.
\end{abstract}

Keywords: anaplastic pancreatic carcinoma; APC; MCN; osteoclast-like giant cell; pancreatic cystic lesion; spindle cell

\section{Case Report}

A 36-year-old female presented with 5 days of abdominal pain, associated nausea, and a firm and tender left hypocondrium. She had no personal nor family history of pancreatitis or solid organ malignancy, and denied any history of alcohol, tobacco, or illicit drug use. After an unremarkable abdominal radiograph, the patient underwent a computed tomography (CT) scan of her abdomen and pelvis that showed a $10 \mathrm{~cm}$ complex cystic mass in the tail of the pancreas (TOP).

An upper endoscopy with endoscopic ultrasound confirmed a $10 \times 8 \mathrm{~cm}$ lesion in the TOP. The lesion was thick walled with multiple internal septations and both cystic and solid components. The serum carcinoembryonic antigen (CEA) level was $2.4 \mathrm{ng} / \mathrm{mL}$ (reference range $0.0-3.0 \mathrm{ng} / \mathrm{mL}$ ) and CA-19 was elevated to $1175 \mathrm{U} / \mathrm{mL}$ (reference range $0.0-35.0 \mathrm{U} / \mathrm{mL}$ ). The differential diagnosis for this lesion included a mucinous cystic neoplasm $(\mathrm{MCN})$ or a solid pseudopapillary neoplasm. Fine needle aspiration of the cyst tissue and fluid was obtained that yielded papillary clusters of cells with mild cytological atypia, suspicious for neoplasm. The cystic fluid had a CEA level of $>4000 \mathrm{ng} / \mathrm{mL}$ and an amylase level of $25 \mathrm{U} / \mathrm{L}$.

She underwent a staging CT of chest, abdomen, and pelvis, which again showed the already mentioned mass and no evidence of metastatic disease (Fig. 1).

Based on the size of the lesion, an open distal pancreatectomy and splenectomy were performed. On frozen

Departments of ${ }^{1}$ Surgery and ${ }^{2}$ Pathology, University of Colorado Anschutz Medical Campus, Aurora, Colorado.

*Address correspondence to: Richard D. Schulick, MD, MBA, Department of Surgery, University of Colorado Anschutz Medical Campus, 12631 East 17 th Avenue, Aurora, CO 80045, E-mail: richard.schulick@ucdenver.edu

(C) Alessandro Paniccia et al. 2017; Published by Mary Ann Liebert, Inc. This is an Open Access article distributed under the terms of the Creative Commons Attribution License, which permits unrestricted use, distribution, and reproduction in any medium, provided the original work is properly cited. 

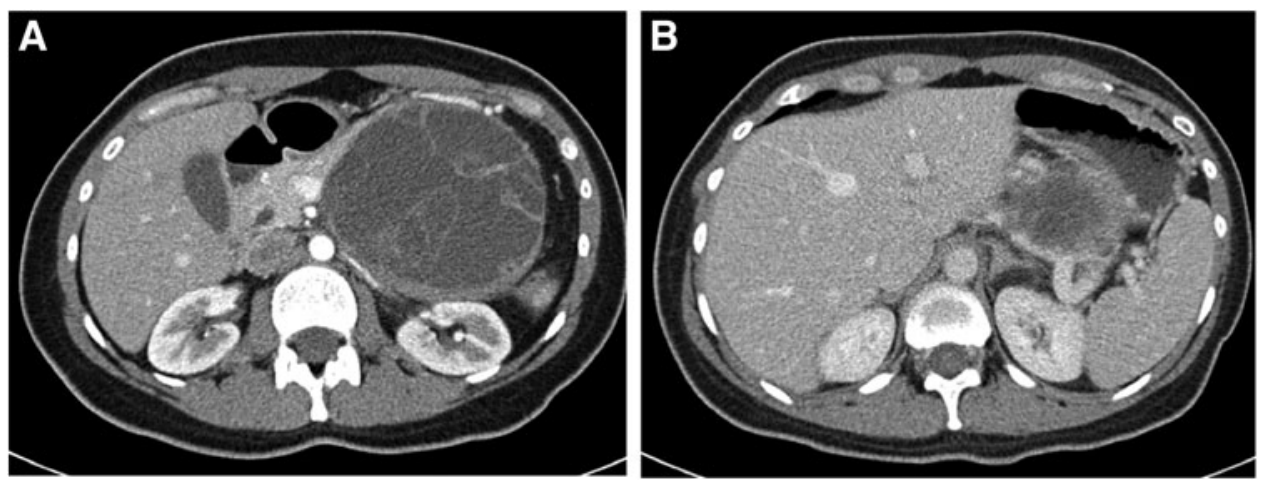

FIG. 1. (A) $10 \times 8 \mathrm{~cm}$ thick walled lesion with multiple thick internal septations and both cystic and solid components in the tail of the pancreas. (B) Splenic vein compression by the mass.

section, the pancreatic margin was found to be normal pancreas parenchyma with low-grade PanIN. The patient had an uneventful postoperative course and was discharged home on postoperative day 6.

Initial pathology sections of the cyst revealed an MCN with extensive high-grade dysplasia (HGD) and a few foci of microscopic invasive well-differentiated adenocarcinoma (Fig. 2A, B; Table 1). The remainder of the specimen was submitted for histological examination. Areas of undifferentiated malignancy with sarcomatous features were noted in some of the last histological sections (Fig. 2C). The lesion was negative for all mesenchymal markers but strongly positive for cytokeratin (CK), indicating an epithelial malignancy consistent with anaplastic pancreatic carcinoma (APC) (Fig. 2D). Three of 38 peripancreatic lymph nodes were positive for APC, highlighted on CK stain (Fig. 2E, F). The final pancreatic margin was negative for MCN, HGD, and malignancy.

The patient recovered well from the surgical resection and was seen in follow-up at 6 months from the date of surgery at which time a surveillance CT of abdomen did not reveal any evidence of recurrent disease. At her subsequent 8-month follow-up, she had completed six cycles of adjuvant chemotherapy (gemcitabine plus capecitabine) and had an Eastern Cooperative Oncology Group performance score of 1 .

\section{Discussion}

In this study, we describe a rare case of APC originating from a large pancreatic MCN lesion with final histological analysis revealing areas of adenocarcinoma, as well as foci of APC amid mucinous cystadenoma epithelium.
APCs are among the least frequently encountered pancreatic malignancies, ranging from $0.5 \%$ to $7 \%$ of all nonendocrine pancreatic malignancies. ${ }^{1,2}$

APCs are defined as epithelial malignancies, which are composed largely of neoplastic cells with no identifiable line of differentiation. According to the classification of the World Health Organization of tumors of the digestive system, APCs include the following entities: anaplastic carcinoma, undifferentiated carcinoma with osteoclast-like giant cells, pleomorphic giant cell carcinoma, undifferentiated carcinoma, pleomorphic carcinoma, and sarcomatoid carcinoma, among others. ${ }^{3,4}$

To the best of our knowledge, only 12 cases of anaplastic carcinoma arising from MCNs are reported in the English language literature (Table 2). ${ }^{5-13}$

The most commonly described clinical symptoms in the literature include loss of weight, fatigue, loss of appetite, abdominal pain, nausea, vomiting, and diarrhea. ${ }^{11}$ Despite many morphology changes, the APC cells usually have reactivity to epithelial markers and vimentin, indicating an epithelial origin with dedifferentiation. Diagnosis of this type of tumor may be challenging because of lack of glandular structures or other features that indicate a direction of differentiation. Perineural/lymphovascular invasion is rarely mentioned in the identified case reports and case series of APC originating from MCNs; therefore, the true prevalence of perineural/lymphovascular invasion remains difficult to quantify. For example, Lane and Sangueza were the only authors-among those selected for this review-to describe positive lymphovascular invasion. ${ }^{7}$ Similarly, the rate of metastatic lymph nodes with cellular deposits of APC originating from MCNs remains 

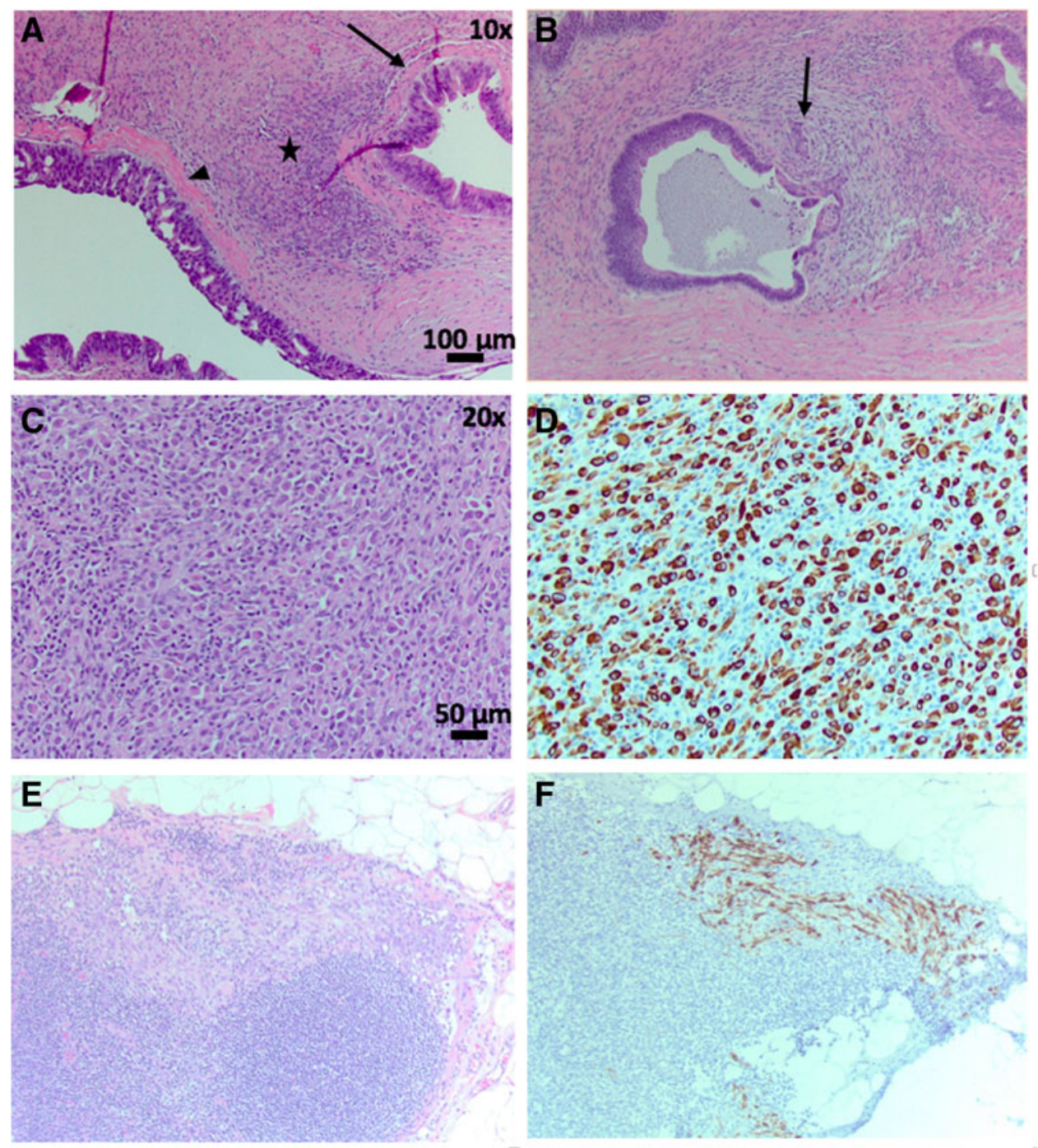

FIG. 2. (A) Representative HE stained section of $M C N$ demonstrating moderate grade (arrow) to high-grade (arrowhead) dysplasia and ovarian stroma (star) $(10 \times)$. (B) Area of invasive pancreatic adenocarcinoma (arrow) within MCN $(10 \times)$. (C) Representative HE region of highly cellular stroma within MCN specimen (20X). (D) Cellular stroma staining CK positive indicating epithelial cell type origin $(20 \times)$. (E, F) Representative lymph node $\mathrm{HE}$ and CK stain showing CK-positive cells invading lymph node tissue $(20 \times)$. CK, cytokeratin; $\mathrm{HE}$, hematoxylin and eosin; MCN, mucinous cystic neoplasm.

unclear, as only 3 of the 10 selected authors reported on the status of the lymph nodes; of these Lane and Sangueza $^{7}$ described positive retroperitoneal lymph nodes involved with APC cellular deposits and, similarly, Nishihara et al. described peripancreatic and perigastric lymph nodes with APC cellular deposits. ${ }^{8}$ In the case herein described, we identified three metastatic lymph nodes with clear evidence of APC cellular deposits.
APCs are historically associated with dismal prognosis, with median overall survival for patients with unresected APC estimated at 3 months and for resected APC estimated at $59.1 \%, 30.7 \%$, and $12.2 \%$, respectively, at 1,2 , and 5 years. ${ }^{2}$

However, survival rates can be quite variable, because of the wide array of histopathology present under the umbrella of APCs. For example, a sarcomatoid lineage of APCs confers a dreadful prognosis, as shown by 
Table 1. Summary of the Histomorphological and Immunohistochemical Features of the Mucinous Cystic Neoplasm Described in the Case Report

Histomorphology

Immunohistochemistry

MCN with abundant ovarian-type stroma (confirmed by positive ER/PR) with extensive high-grade dysplasia. Microscopic foci of invasive adenocarcinoma budding off the main epithelial lining.

Multiple hypercellular areas, comprising markedly atypical cells without glandular differentiation. Atypical cells appear spindled or rhabdoid with eccentrically placed nuclei and dense purple cytoplasm.

SMA, desmin, myogenin, CD10, and INI1 are negative in the hypercellular areas, arguing against a diagnosis of sarcoma.

Pancytokeratin and CK 7 are strongly and diffusely positive in the hypercellular areas, including the spindled and rhabdoid-appearing cells. EMA is weakly positive in the same population of cells. This staining pattern is most consistent with undifferentiated carcinoma (anaplastic carcinoma).

CK, cytokeratin; EMA, epithelial membrane antigen; ER, estrogen receptor; $M C N$, mucinous cystic neoplasm; PR, progesterone receptor; SMA smooth muscle actin.

Wenig et al., with two of three patients deceased within 15 months from diagnosis. ${ }^{14}$ On the contrary, the osteoclast-like giant cell feature appears to confer a favorable prognosis with 5 -year survival of $50 \% .{ }^{4}$ Another open debate in the APCs literature is the pathogenesis of these lesions with recent evidence suggesting a monoclonal origin with subsequent differentiation toward an epithelial or a mesenchymal neoplastic component. ${ }^{15,16}$

The choice of systemic therapy after surgical resection of APC remains an open question as no high- quality studies have been completed comparing one adjuvant regimen versus another and, therefore, no consensus has been reached regarding the optimal adjuvant therapy. Several different adjuvant regimens have been described, including the use of adjuvant paclitaxel, S-1 (based on the result of the JASPAC-01 trial), and gemcitabine, among others. ${ }^{13,17-19}$ The choice seems to be driven by institutional preferences, and perhaps by the particular histological subtype of APC and associated molecular markers-although no

Table 2. Anaplastic Pancreatic Carcinoma Arising from Mucinous Cystic Neoplasm, Reported Cases in the Literature

\begin{tabular}{|c|c|c|c|c|c|c|c|}
\hline Authors & Years & $\begin{array}{l}\text { No. of } \\
\text { cases }\end{array}$ & Age/gender & $\begin{array}{l}\text { MCN } \\
\text { greatest } \\
\text { dimension }\end{array}$ & $\begin{array}{l}\text { Morphology } \\
\text { of anaplastic } \\
\text { component }\end{array}$ & $\begin{array}{l}\text { Adjuvant } \\
\text { therapy }\end{array}$ & Follow-up \\
\hline $\begin{array}{l}\text { García Rego } \\
\text { et al. }{ }^{5}\end{array}$ & 1991 & 1 & 45/Female & $11 \mathrm{~cm}$ & $\begin{array}{l}\text { Anaplastic carcinoma with } \\
\text { transition from spindle } \\
\text { cells to neoplastic } \\
\text { glandular elements }\end{array}$ & ND & $\begin{array}{l}\text { Alive at } 16 \text { months after } \\
\text { diagnosis }\end{array}$ \\
\hline $\begin{array}{l}\text { Marinho } \\
\text { et al. }\end{array}$ & 1995 & 1 & 70/Female & $4.5 \mathrm{~cm}$ & Dispersed anaplastic cells & ND & ND \\
\hline \multirow[t]{2}{*}{$\begin{array}{l}\text { Wenig } \\
\text { et al. }^{14}\end{array}$} & 1996 & 3 & $\begin{array}{l}\text { 48/Female } \\
66 / \text { Female }\end{array}$ & $\begin{array}{l}19 \mathrm{~cm} \\
\mathrm{ND}\end{array}$ & Spindle cell & $\begin{array}{l}\text { ND } \\
\text { ND }\end{array}$ & $\begin{array}{l}\text { Alive for } 1 \text { year } \\
\text { Died after } \\
9 \text { months }\end{array}$ \\
\hline & & & 67/Male & $30 \mathrm{~cm}$ & & ND & $\begin{array}{l}\text { Died after } \\
15 \text { months }\end{array}$ \\
\hline $\begin{array}{l}\text { Lane and } \\
\quad \text { Sangueza }\end{array}$ & 1996 & 1 & 25/Female & & Anaplastic morphology & ND & $\begin{array}{l}\text { Alive } 6 \text { months after diagnosis } \\
\text { with liver metastatic disease }\end{array}$ \\
\hline $\begin{array}{l}\text { Nishihara } \\
\text { et al. }{ }^{8}\end{array}$ & 1997 & 1 & 52/Female & $10 \mathrm{~cm}$ & $\begin{array}{l}\text { Anaplastic with rhabdoid } \\
\text { feature }\end{array}$ & ND & Died 19 months after diagnosis \\
\hline $\begin{array}{l}\text { Bloomston } \\
\text { et al. }{ }^{9}\end{array}$ & 2006 & 1 & 67/Female & $4 \mathrm{~cm}$ & $\begin{array}{l}\text { Spindle cell morphology in } \\
\text { addition to poorly } \\
\text { differentiated and } \\
\text { squamous areas }\end{array}$ & $\begin{array}{l}\text { Did not } \\
\text { receive }\end{array}$ & Died 4 months after diagnosis \\
\hline $\begin{array}{l}\text { Pan and } \\
\text { Wang }^{11}\end{array}$ & 2007 & 1 & 70/Female & $10.4 \mathrm{~cm}$ & $\begin{array}{l}\text { Anaplastic with predominant } \\
\text { spindle cell component }\end{array}$ & ND & Alive 4 months after diagnosis \\
\hline $\begin{array}{l}\text { Hakamada } \\
\text { et al. }{ }^{10}\end{array}$ & 2008 & 1 & 38/Female & $5 \mathrm{~cm}$ & $\begin{array}{l}\text { Spindle cell, giant cells, } \\
\text { and adenocarcinoma }\end{array}$ & ND & Alive at 4 years \\
\hline $\begin{array}{l}\text { Asberry } \\
\text { et al. }{ }^{12}\end{array}$ & 2012 & 1 & 40/Female & $8 \mathrm{~cm}$ & Spindle cell morphology & ND & Alive 48 months after diagnosis \\
\hline 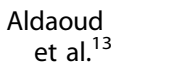 & 2016 & 1 & 37/Female & $10 \mathrm{~cm}$ & $\begin{array}{l}\text { Highly dyscohesive anaplastic } \\
\text { cells }\end{array}$ & Gemcitabine & Died 7 months after diagnosis \\
\hline $\begin{array}{l}\text { Paniccia et al. } \\
\text { (present } \\
\text { study) }\end{array}$ & 2017 & 1 & 36/Female & $16 \mathrm{~cm}$ & $\begin{array}{l}\text { Anaplastic with predominant } \\
\text { spindle cell morphology in } \\
\text { addition to multifocal } \\
\text { invasive adenocarcinoma }\end{array}$ & $\begin{array}{l}\text { Gemcitabine } \\
\text { and } \\
\text { capecitabine }\end{array}$ & Alive at 5 months \\
\hline
\end{tabular}

ND, not described 
definitive agreement exists. We elected to administer a gemcitabine-based regimen - which has been proven to be efficacious in the adjuvant setting after resection of pancreatic adenocarcinoma-combined with capecitabine based on the data published in the ESPAC-4 trial showing increased response with acceptable toxicity profile. ${ }^{20}$

Specifically, the patient herein discussed received adjuvant gemcitabine $\left(1000 \mathrm{mg} / \mathrm{m}^{2}\right.$ intravenously on days 1,8 , and 15 every 28 days) with the addition of capecitabine $\left(1600 \mathrm{mg} / \mathrm{m}^{2}\right.$-in divided doses-on day 1 through day 21 every 28 days), and completed a total of six cycles with moderate systemic toxicity.

Finally, it is worth noting that malignant transformation-within the MCN lesion-is characterized by a focal skip pattern, wherein isolated areas of cancerous transformation can be found alongside normalappearing cyst epithelial lining. ${ }^{12}$ Therefore, partial or inaccurate cyst wall analysis can easily lead to misdiagnosis and the importance of a thorough pathological evaluation of the entire cyst wall cannot be overstated.

In fact, complete operative resection of MCNs lacking an invasive component (i.e., benign $\mathrm{MCNs}$ and, more importantly, noninvasive proliferative $\mathrm{MCNs}$ ) ensures cure. ${ }^{21}$ These neoplasms are solitary and do not recur either locally or distally after complete operative resection. ${ }^{21}$ On the contrary, the presence of an invasive component-within the $\mathrm{MCN}$-mandates that this lesion is treated similarly to pancreatic ductal adenocarcinoma (PDAC) for what concerns adjuvant therapy and follow-up, because of the high risk of local and systemic recurrence. ${ }^{21,22}$ Invasive adenocarcinoma arising within an MCN lesion appears to have a slightly different behavior from the more common PDAC arising de novo from the pancreatic duct. In fact, most series describe a lower rate of lymph node positivity ranging from $0 \%$ to $34 \%$ and a more favorable 3 -year survival rate, ranging from $44 \%$ to $83 \%{ }^{23-28}$ Although it remains unclear whether this seemingly more indolent behavior of adenocarcinoma arising from pancreatic MCNs-compared with the de novo PDAC-is the result of actual biological differences or whether it is just a consequence of diagnosis and resection at an earlier cancer stage.

It is the authors' practice-in the setting of MCNsto perform extensive, preferably complete, sampling of the cyst wall to (1) rule out malignancy and (2) rule out the presence of more than one kind of malignancy. In this case, the minute microscopic foci of adenocarcinoma are of less clinical consequence than the APC that was found only because the entire lesion was scrupulously analyzed rather than stopping after the identification of the adenocarcinoma component. This case argues for scrupulous pathological evaluation of the entire $\mathrm{MCN}$ and adds to the limited world literature of APC originating from pancreatic MCNs.

\section{Author Disclosure Statement}

No competing financial interests exist.

\section{References}

1. Strobel O, Hartwig W, Bergmann F, et al. Anaplastic pancreatic cancer: presentation, surgical management, and outcome. Surgery. 2011;149:200-208.

2. Clark CJ, Graham RP, Arun JS, et al. Clinical outcomes for anaplastic pancreatic cancer: a population-based study. J Am Coll Surg. 2012;215:627-634.

3. Bosman FT, Carneiro F, Hruban RH. WHO Classification of Tumours of the Digestive System. Lyon, France: World Health Organization, 2010, p. 1

4. Paniccia A, Hosokawa PW, Schulick RD, et al. A matched-cohort analysis of 192 pancreatic anaplastic carcinomas and 960 pancreatic adenocarcinomas: A 13-year North American experience using the National Cancer Data Base (NCDB). Surgery. 2016;160:281-292.

5. García Rego JA, Valbuena Ruvira L, Alvarez García A, et al. Pancreatic mucinous cystadenocarcinoma with pseudosarcomatous mural nodules. A report of a case with immunohistochemical study. Cancer. 1991;67:494-498.

6. Marinho A, Nogueira R, Schmitt F, et al. Pancreatic mucinous cystadenocarcinoma with a mural nodule of anaplastic carcinoma. Histopathology. 1995;26:284-287.

7. Lane RB, Sangueza OP. Anaplastic carcinoma occurring in association with a mucinous cystic neoplasm of the pancreas. Arch Pathol Lab Med. 1997;121:533-535.

8. Nishihara K, Katsumoto F, Kurokawa Y, et al. Anaplastic carcinoma showing rhabdoid features combined with mucinous cystadenocarcinoma of the pancreas. Arch Pathol Lab Med. 1997;121:1104-1107.

9. Bloomston M, Chanona-Vilchis J, Ellison EC, et al. Carcinosarcoma of the pancreas arising in a mucinous cystic neoplasm. Am Surg. 2006;72:351355.

10. Hakamada K. Anaplastic carcinoma associated with a mucinous cystic neoplasm of the pancreas during pregnancy: report of a case and a review of the literature. World J Gastroenterol. 2008;14:132-134.

11. Pan ZG, Wang B. Anaplastic carcinoma of the pancreas associated with a mucinous cystic adenocarcinoma. A case report and review of the literature. JOP. 2007;8:775-782.

12. Asberry DE, Youngberg GA, Al-Abbadi MA. Mucinous cystic neoplasm of the pancreas with neuroendocrine cells and malignant stroma. Saudi Med J. 2013;34:80-85.

13. Aldaoud N, Joudeh A, Al-Momen S, et al. Anaplastic carcinoma arising in a mucinous cystic neoplasm masquerading as pancreatic pseudocyst. Diagn Cytopathol. 2016;44:538-542.

14. Wenig BM, Albores-Saavedra J, Buetow PC, et al. Pancreatic mucinous cystic neoplasm with sarcomatous stroma: a report of three cases. Am J Surg Pathol. 1997;21:70-80.

15. van den Berg W, Tascilar M, Offerhaus GJ, et al. Pancreatic mucinous cystic neoplasms with sarcomatous stroma: molecular evidence for monoclonal origin with subsequent divergence of the epithelial and sarcomatous components. Mod Pathol. 2000;13:86-91.

16. Hoshimoto S, Matsui J, Miyata R, et al. Anaplastic carcinoma of the pancreas: case report and literature review of reported cases in Japan. World J Gastroenterol. 2016;22:8631-8638.

17. Fujiogi M, Kobayashi T, Yasuno M. Anaplastic carcinoma of the pancreas mimicking submucosal gastric tumor: a case report of a rare tumor. Case Rep Med. 2013:523237.

18. Nitta T, Fujii K, Kataoka J, et al. A case of long-term 24-month survival in pancreatic anaplastic carcinoma (giant cell type) after S1 postoperative adjuvant chemotherapy. Int J Surg Case Rep. 2016;23:134-137. 
19. Uesaka K, Fukutomi A, Boku N, et al. Randomized phase III trial of adjuvant chemotherapy with gemcitabine versus S-1 for patients with resected pancreatic cancer (JASPAC-01 study). J Clin Oncol. 2013;31(4 Suppl):145

20. Neoptolemos JP, Palmer DH, Ghaneh P, et al. Comparison of adjuvant gemcitabine and capecitabine with gemcitabine monotherapy in patients with resected pancreatic cancer (ESPAC-4): a multicentre, openlabel, randomised, phase 3 trial. Lancet. 2017;389:1011-1024.

21. Sakorafas GH, Smyrniotis V, Reid-Lombardo KM, et al. Primary pancreatic cystic neoplasms revisited: Part II. Mucinous cystic neoplasms. Surg Oncol. 2011;20:e93-e101.

22. Stark A, Donahue TR, Reber HA, et al. Pancreatic cyst disease. JAMA. 2016;315:1882-1893.

23. Postlewait LM, Ethun CG, McInnis MR, et al. Association of preoperative risk factors with malignancy in pancreatic mucinous cystic neoplasms. JAMA Surg. 2017;152:19-25.

24. Jang K-T, Park SM, Basturk O, et al. Clinicopathologic characteristics of 29 invasive carcinomas arising in 178 pancreatic mucinous cystic neoplasms with ovarian-type stroma: implications for management and prognosis. Am J Surg Pathol. 2015;39:179-187.

25. Sarr MG, Carpenter HA, Prabhakar LP, et al. Clinical and pathologic correlation of 84 mucinous cystic neoplasms of the pancreas: can one reliably differentiate benign from malignant (or premalignant) neoplasms? Ann Surg. 2000;231:205-212.

26. Gil $\mathrm{E}$, Choi SH, Choi DW, et al. Mucinous cystic neoplasms of the pancreas with ovarian stroma. ANZ J Surg. 2013;83:985-990.

27. Crippa S, Salvia R, Warshaw AL, et al. Mucinous cystic neoplasm of the pancreas is not an aggressive entity: lessons from 163 resected patients. Ann Surg. 2008;247:571-579.
28. Yamao K, Yanagisawa A, Takahashi K, et al. Clinicopathological features and prognosis of mucinous cystic neoplasm with ovarian-type stroma: a multi-institutional study of the Japan pancreas society. Pancreas. 2011;40:67-71.

Cite this article as: Paniccia A, Torphy R, Devaraj K, Schulick RD (2017) Anaplastic pancreatic carcinoma arising within a mucinous cystic neoplasm of the pancreas: a case report and a brief review of the literature, Journal of Pancreatic Cancer 3:1, 40-45, DOI: 10.1089/ pancan.2017.0004.

\section{Abbreviations Used}

APC $=$ anaplastic pancreatic carcinoma

$\mathrm{CK}=$ cytokeratin

$\mathrm{CT}=$ computed tomography

$\mathrm{HE}=$ hematoxylin and eosin

$\mathrm{HGD}=$ high-grade dysplasia

MCN = mucinous cystic neoplasm

$\mathrm{PDAC}=$ pancreatic ductal adenocarcinoma

TOP $=$ tail of the pancreas

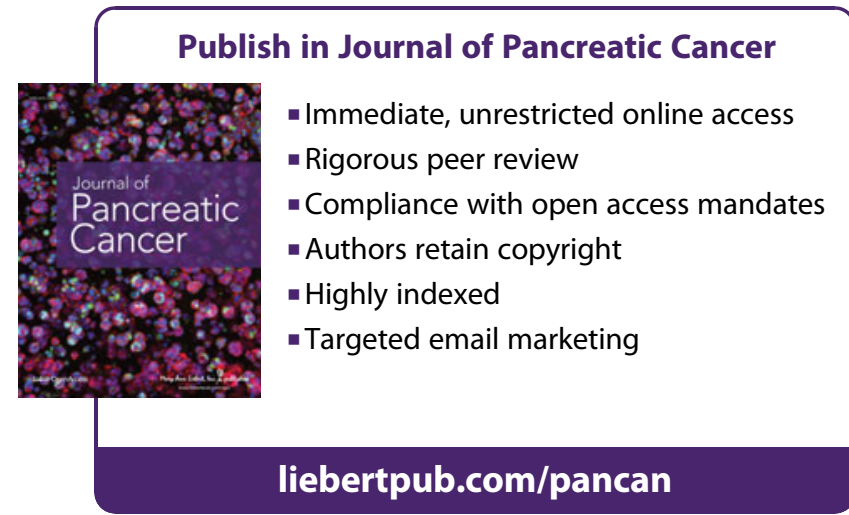

